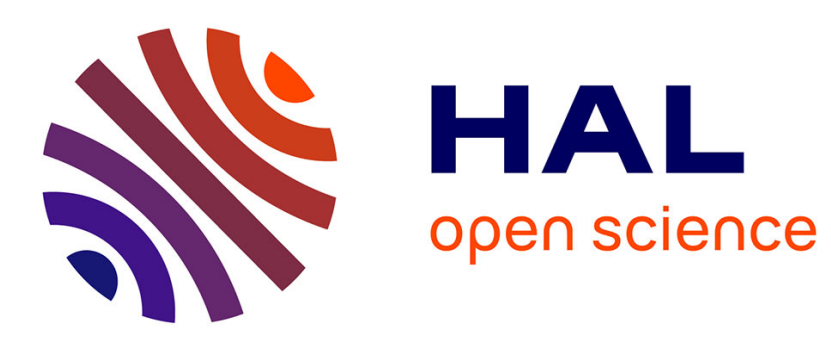

\title{
How can a bourdieusian perspective aid analysis of MBA education?
}

\author{
Eero Vaara, Eric Faÿ
}

\section{To cite this version:}

Eero Vaara, Eric Faÿ. How can a bourdieusian perspective aid analysis of MBA education?. Academy of Management Learning and Education (AMLE), 2011, 10 (1), pp.27-39 P. hal-02276712

\section{HAL Id: hal-02276712 \\ https://hal.science/hal-02276712}

Submitted on 3 Sep 2019

HAL is a multi-disciplinary open access archive for the deposit and dissemination of scientific research documents, whether they are published or not. The documents may come from teaching and research institutions in France or abroad, or from public or private research centers.
L'archive ouverte pluridisciplinaire HAL, est destinée au dépôt et à la diffusion de documents scientifiques de niveau recherche, publiés ou non, émanant des établissements d'enseignement et de recherche français ou étrangers, des laboratoires publics ou privés. 


\title{
How Can a Bourdieusian Perspective Aid Analysis of MBA Education?
}

\author{
EERO VAARA \\ Hanken School of Economics, Helsinki, and EMLYON Business School, France \\ ERIC FÄ̈̈ \\ EMLYON Business School
}

\begin{abstract}
There is a lack of integrative conceptual models that would help to better understand the underlying reasons for the alleged problems of MBA education. To address this challenge, we draw on the work of Pierre Bourdieu to examine MBA education as an activity with its own "economy of exchange" and "rules of the game." We argue that application of Bourdieu's theoretical ideas elucidates three key issues in debate around MBA education: the outcomes of $M B A$ programs, the inculcation of potentially problematic values and practices through the programs, and the potential of self-regulation, such as accreditation and ranking for impeding development of MBA education. First, Bourdieu's notions of capital-intellectual, social, and symbolic-shed light on the "economy of exchange" in $M B A$ education. Critics of MBA programs have pointed out that the value of MBA degrees lies not only in "learning." Bourdieu's framework allows further analysis of this issue by distinguishing between intellectual (learning), social (social networks), and symbolic capital (credentials and prestige). Second, the concept of "habitus" suggests how values and practices are inculcated through $M B A$ education. This process is often one students acquire voluntarily, and students often regard problematic or ethically questionable ideas as natural. Third, Bourdieu's reflections on the "doxa" and its reproduction and legitimation illuminate the role of accreditation and ranking in MBA education. This perspective helps to understand how self-regulation may impede change in $M B A$ education.
\end{abstract}

Scholars have directed increasing attention to problems associated with MBA programs. Prominent researchers have argued that traditional MBA programs concentrate excessively on theories instead of providing practical skills (Leavitt, 1989; Mintzberg, 2004; Bennis \& O'Toole, 2005). Others have concentrated on ethical issues and argued that MBA programs are one reason for the serious problems encountered in contemporary management (French \& Grey, 1996; Mintzberg, 2004; Ghoshal, 2005; Khurana, 2007). Furthermore, others have reflected on the role of rankings (DeNisi, 2008; Glick, 2008; Zemsky, 2008) and accreditation (Julian \& Ofori-Dankwa, 2006; Romero, 2008; Zammuto, 2008) as potential impediments to change.

While extant studies have provided important insights into the problems of MBA education, this critique has been limited by a lack of integrative conceptual models that would allow examination of the underlying reasons for the above problems. With this in mind, we drew from the work of the French anthropologist and sociologist Pierre Bourdieu (1930-2002) to better understand MBA education as an educational activity with its own "economy of exchange" and "rules of the game." Researchers across the social sciences have been inspired by Bourdieu's work, and management scholars have also used his theories in various topic areas (Oakes, Townley, \& Cooper, 1998; Ramirez, 2001; Mutch, 2003; Özbilgin \& Tatli, 2005; Mutch, Delbridge, \& Ventresca, 2006; Golsorki, Leca, Lounsbury, \& Ramirez, 2009). Strangely enough, however, his ideas have not been systematically applied to discussion of MBA education.

An essential part of Bourdieu's work has concentrated on higher education (Bourdieu, 1970, 1984/ 
1988, 1989/1998; Bourdieu \& Passeron, 1990). In these and other pieces of work, he focused attention on the characteristics of the educational field and its relations to other fields in society, the central role of pedagogical authority (the authority of educational institutions), various forms of "capital" that are produced and exchanged in educational activities, the habitus (set of dispositions) that is inculcated in educational activities, and the doxa (fundamental beliefs of the field) that is reproduced and at times transformed in education (Bourdieu, 1980/1990, 1996). Bourdieu's work thus provides an integrative conceptual framework that helps us to understand some of the essential structural features of MBA education that may be seen as the cause of the alleged problems.

We argue here that Bourdieu's theories can elucidate three key issues in the ongoing debate about MBA programs: the outcomes of MBA programs, inculcation of values and practices in the process, and self-regulation in the form of accreditation and ranking as a potential impediment to development of the programs. First, we argue that Bourdieu's notions of capital-intellectual, social, and symbolic-can help to explain the "economy of exchange" in MBA education. Critics of MBA programs (Pfeffer \& Fong, 2002; Khurana, 2007) have pointed out that the value of MBA degrees does not only lie in learning. Bourdieu's fromework furthers analysis of this issue by distinguishing between intellectual (learning), social (social networks), and symbolic capital (credentials and prestige) as essential parts of the economy of exchange. Second, the concept of "habitus" helps us to understand exactly how values and practices are inculcated in the process of MBA education. This process is often a "voluntary" one, where problematic or ethically questionable ideas may also be internalized and accepted as natural. Third, in relation to the education system itself, Bourdieu's reflections on "doxa" and its reproduction and legitimation illuminate the role of accreditation (DeNisi, 2008; Glick, 2008; Zemsky, 2008) and ranking systems in MBA education (Julian \& OforiDankwa, 2006; Romero, 2008; Zammuto, 2008). An analysis of such self-regulation explains in part how the system may either impede or promote change.

Our analysis-following Bourdieu's example-is deliberately critical and provocative. This does not mean that we ignore the value of MBA programs or attempts to improve them. On the contrary, we wish to clarify the underlying issues and critical debates precisely in order to develop MBA programs and education more generally. We focus on classic MBA programs that follow the North Amer- ican model. Although on essential part of the critique may be valid for management education in general, it is important to appreciate the differences between various kinds of MBA programs and other types of management education.

\section{CRITIQUE OF MBA EDUCATION}

Viewing business education or MBA programs from a critical perspective is nothing new. For example, the establishment of university-based business schools-such as Harvard-was largely the result of critical discussion about the need to professionalize what the "men of business" were doing (Cruikshank, 1987; Khurana, 2007). The creation of the AACSB in 1961 can, in turn, be seen as an attempt to deal with growing concerns about the quality of management education in general and of MBA education in particular (Khurana, 2007). However, criticism of MBA programs intensified in the 2000s alongside the emergence of more systematic and scholarly discussion of management education (Grey \& French, 1996; Chia, 2005; Donaldson, 2005; Khurana, 2007; Mintzberg, 2004; Pfeffer \& Fong, 2002; Pfeffer, 2005; Spender, 2005; Wensley, 2005). In particular, Mintzberg's (2004) thoughts have resulted in heated debate (Chia, 2005; Donaldson, 2005; Pfeffer, 2005; Wensley, 2005). Rather than providing a full review of this discussion, we will highlight three crucial issues: whether the programs provide useful knowledge to students, whether the education process leads students to adopt ethically questionable values and practices, and whether accreditation and rankings impede or promote change in the programs.

First, a large part of the criticism has focused on the outcome: the knowledge and learning provided by MBA education. Leavitt (1989) already argued that traditional MBA programs deliver highly standardized knowledge without a clear linkage to practice. Mintzberg (2004) has accused MBA programs of "scientificity" and a lack of attention to practical experience. For many, the fundamental issue is the traditional way theory is taught and spread in MBA courses (Linder, Smith, \& Jeff, 1992; Pinington, 2005; Starkey, Hatchuel, \& Tempest, 2004). Critics have also pointed to a strong emphasis on specialization instead of on development of cross-functional abilities (Gosling \& Mintzberg, 2004; Latham, Latham, \& Whyte, 2004). MBA programs have been referred to as "silos" without sufficient integrative elements (Navarro, 2008). The need to focus on "softer" areas, such as people management, interpersonal interaction, and leadership skills has also been discussed extensively (Cheit, 1985; Mintzberg, 2004). 
The solutions offered are inspired by new approaches to executive education aimed at linking theory and practice and at bridging the gap between academic knowledge and practical experience. For example, Crotty and Soule (1997) suggest a more active involvement of companies in the design of MBA programs. Among others, Gosling and Mintzberg (2004) propose that to be able to immediately apply and share theoretical knowledge in relation to actual problems, MBA programs should only enroll managers who are also engaged in work. Mintzberg's IMPM program is a well-known example of theoretical tools combined with lived experience (Mintzberg, 2004). However, others have been more pessimistic about prospects for remedying these problems. For example, Pfeffer and Fong $(2002,2004)$ have argued that MBA programs are primarily a "business," where educational results are of secondary importance.

Second, another strand of critique has emphasized the process through which students may adopt problematic values and ethically questionable practices. In particular, critical management scholars have focused on ideological issues (Grey \& French, 1996; Knights, 2008), while others have concentrated on values and ethics (Khurana, 2007; Mintzberg, 2004). Grey's (2002) critique of management education is that MBA programs socialize students into "managerialism" and "turbocapitalism," which reproduce one-sided thinking and problematic practices. Khurana (2007) has argued that during the past few decades the original professional ideals have been replaced by an ideology of "market capitalism," which is internalized by the students. "Instrumentalism" and a lack of "humanism" have also been central themes in this critique (Parker \& Jary, 1995; Sturdy \& Gabriel, 2000). In addition, scholars have criticized MBA programs from a feminist standpoint (Simpson, 2006). Due to the overwhelming influence of Western or Anglo-American worldviews, the "ethnocentrism" and "neocolonialism" of MBA education has also been criticized (Costea, 1999; Mellahi, 2000; Parker \& Jary, 1995; Üsdiken, 2004). Mintzberg (2004) goes so far as to state that in their present form, MBA programs lead to corruption of the educational process, managerial practice, established organizations, and social institutions. Ghoshal has put it as follows: "Business schools do not need to do a great deal more to prevent future Enrons; they need only to stop doing a lot they currently do" (Ghoshal, 2005: 75).

Bringing in more critical reflection on management has been offered as a means to deal with such ideological and ethical problems. Reynolds (1999) has spoken for a "critical management ped- agogy" that would build on critical reflection and less hierarchical approaches to learning. Currie and Knights (2003) have proposed new approaches to develop deeper level critical understanding in MBA education. However, integration of critical thinking into MBA courses and programs has encountered resistance (Hogen, Miller, \& Johnson, 2003). For example, Hagen et al. (2003) have reported problems with introducing "well-intended" and "advanced" learning methods to MBA students who expect something else. Fenwick (2005) has, in turn, described struggles related to the justification of critical interventions that conflict with students' beliefs and values.

A third stream of critique has concentrated on the system itself-especially on the role of accreditation agencies and ranking. In particular, Khurana's (2007) institutional analysis of business schools has highlighted the importance of professional self-regulation. On the whole, accreditation agencies-AACSB, EQUIS and AMBA among others-have been seen as a means for developing the system; in particular, the standards of MBA programs. However, critical scholars have seen these agencies as impediments to change. Julian and Ofori-Dankwa (2006) provocatively argued that as an "accreditocracy," these institutions are harmful in terms of preventing needed change. Others have defended accreditation processes and highlighted their role in quality improvement (Romero, 2008; Zammuto, 2008) and in the development of MBA programs (Moskal, Ellis, \& Keon, 2008).

Ranking systems have also emerged, and their role has been accentuated in the increasing global competition for MBA students. Although these rankings emphasize the value of an MBA degree in the job market, their implications have been debated. In brief, they have-among other thingsbeen accused of promoting only particular kinds of standard models-and thus impeding the longer term development of MBA programs (DeNisi, 2008; Glick, 2008).

In all, these and other studies have provided important insights into the problems of MBA education. However, we lack theoretical models that would elucidate the structural features of this educational activity, and thereby, shed light on the underlying reasons for these problems and the controversial experiences in bringing about change. For this purpose, we now turn to the work of Bourdieu, which provides an inspiring theoretical basis for a scrutiny of the economy of exchange and rules of the game in this educational system. 


\section{BOURDIEU ON EDUCATION}

A thorough review of Bourdieu's work is beyond our scope here (for extensive reviews, see Calhoun, LiPuma, \& Postone, 1992; Fowler, 1997; Lane, 2000; Robbins, 2005; Wacquant, 2005; Özbilgin \& Tatli 2005). We will instead provide a brief overview of his central theoretical ideas and then concentrate on specific findings in his studies on academic education.

Bourdieu viewed society as a complex of interlinked fields and subfields such as education. He saw most fields in society as governed by an exchange of capital and emphasized that actors have access to and strive to gain various forms of capitol (Bourdieu, 1980). In his work, Bourdieu distinguished between economic, cultural (including intellectual), social (including networks), and symbolic (including linguistic) copital. In his fromework, forms of capital can be and are frequently converted into other kinds of capital. Important as well is that symbolic capital is closely linked to habitus-another key concept in Bourdieu's work.

According to Bourdieu, socialization, which includes primary (childhood) and secondary (education) socialization, leads to the embodiment of particular dispositions. To underline the central role of these dispositions, Bourdieu used the term, habitus. This is a system of durable dispositions that people have acquired through socialization (Bourdieu, 1980, 1996). According to this view, a habitus is an internalized system of schemes for perceiving, thinking, feeling, and acting within a given field and its structures. Bourdieu's analysis thus provides the connection between the subjective (individuals) and the objective (structures). This habitus is not to be conceived as a principle of determination but as a generative structure. Thus, education provides or reinforces specific dispositions, but does not as such determine the actions of graduates.

In Bourdieu's framework, fields such as education have their own doxa (fundamental beliefs that are shared by the actors). Actors within the social field in question have specific positions; some of these positions are more central and others more distant. This creates political tension in the field as actors struggle and maneuver for more central positions. A key objective in Bourdieusian analysis is to uncover how powerful actors-organizations and individuals-succeed in maintaining power relationships by reproduction of the doxa and related values and practices.

Bourdieu also underlines specific features of education. He argued in La Reproduction (1970; in English: Reproduction in Education, Society and
Culture, 1990) that education is the central system in which the social order is reproduced. Actors such as universities and professors have pedagogical authority (PAu) in this system. This PAu ensures that students accept the legitimacy of what they learn and strive to internalize this learning. In Bourdieu's terms, this authority enables pedagogical work (PW) that leads to the creation of capital and inculcation of the habitus. It involves "confirmation," "substitution" or "re-education" of the primary habitus inculcated during previous education stages (Bourdieu, 1970; Bourdieu \& Passeron, 1990). Confirmation takes place in institutions that select only people who already have a habitus close to the one that is to be produced. When students already know the code, PW focuses on exercises that aim at reinforcing assimilation of this code. Bourdieu underscored that in higher education, the secondary PW is frequently built upon the practical and symbolic mastery of a specific kind of language (Bourdieu \& Passeron, 1990).

Bourdieu emphasized that the PAu is nevertheless dependent on the elite's consent, which is shown in the various ways in which education tends to reproduce prevailing values and the power position of the elite. In La Noblesse d'Etat (1989; In English: State Nobility, 1998), Bourdieu showed that within leading French universities, pedagogy was shaped to (re)produce an elite through a selection system that was far from unbiased. Furthermore, the content of the teaching addressed the interests of the elite rather than any "real" needs. Bourdieu underscored that we usually lack the ability to see how this system serves the exclusive interests of the elite and how it affects selection, evaluation, recruiting, and compensation practices in educational institutions.

According to Bourdieu, a more fine-grained analysis has to take into consideration the relations and competition between educational institutions. In Homo Academicus (1984/1998), Bourdieu provided a detailed analysis of the history and status of particular French universities. Moreover, he showed how studying or working in a particular school is linked to one's symbolic capital. In simple terms, a more prestigious university provides its students and faculty with more symbolic capital than a less prestigious one. This has a number of implications that enable and constrain both students and academics.

Two caveats are in order at this stage. First, it is not possible to apply Bourdieu's ideas and findings regarding the French university system directly to MBA programs. For this reason, our aim is not to take his conclusions for granted but instead to use his key theoretical concepts for a contempo- 
rory analysis of MBA programs. Second, Bourdieu has also been criticized for offering an overly deterministic and pessimistic view of power relations and the possibility of personal change (McNay, 1999). We will in the following pursue such interpretations of his work that underline agency and potential for change (Harker, 1984; Reay, 2004).

How then does a Bourdieusian perspective help us to better understand the reasons for the alleged problems in MBA education? We will now focus on three central issues: (1) the role of intellectual, social, and symbolic capital in MBA education; (2) the particular MBA habitus that is created and reinforced through the programs, and (3) the reproduction of the doxa through self-regulation.

\section{OUTCOME: INTELLECTUAL, SOCIAL, AND SYMBOLIC CAPITAL IN MBA PROGRAMS}

To understand the debate about learning outcomes in MBA programs, it is useful to analyze the value or capital involved. On the one hand, MBA programs create capital through the pedagogic activities constituting the program in question. On the other hand, this process also involves the conversion of one type of capital into another. The primary exchange process is that of conversion of economic capital (money that the students pay to the schools) into intellectual, social, and symbolic capital (that the students accumulate during the MBA education). The secondary exchange then takes place when re-entering the job market after the MBA program (when the graduates benefit, e.g., from salary increases). ${ }^{1}$

To simplify things, we will concentrate on intellectual capital (knowledge and skills), social (networks), and symbolic (status and prestige) capital. It should be noted that we thus focus on the intellectual aspects of cultural capital. By so doing, we follow Bourdieu's example in his analysis of the value produced in educational systems (Bourdieu \& Passeron, 1990). It is important to note that these forms of capital are often closely related and, in many instances, reflect aspects of one and the same thing. In brief, we argue that while intellectual (e.g., knowledge of new concepts and methods) capital is important, it is the analysis of the social (e.g., networks created) and especially the

\footnotetext{
${ }^{1}$ Salary increases are a key factor in most surveys of MBA education. However, results of more rigorous analyses of the effects of MBA education have not found positive effects on salaries (Pfeffer \& Fong, 2002, 2004). Nevertheless, rankings indicate that in the case of the leading schools-that serve as an example for others-the MBA degree is constantly associated with salary increases.
}

symbolic capital (e.g., status and prestige) that helps us to broaden our understanding of the inherent problems in MBA programs. Table 1 provides a crude summary of these three forms of capital.

Intellectual capital involves the learning that we usually associate with education. Accordingly, the official rhetoric in MBA education tends to focus on knowledge of new concepts and methods that promote understanding and better management of contemporary organizations. Bourdieu provides a special angle on the problematic aspects of this learning by emphasizing that this knowledge is the product of the historical and cultural development of this education system. Thus, the alleged scientificity (Mintzberg, 2004), instrumentalism (Sturdy \& Gabriel, 2000), ethnocentrism (Mellahi, 2000), and neocolonialism (Mazza, Sahlin-Anderson, \& Strangaard Pedersen, 2005) are features that have been ingrained in MBA programs over a period of time. Hence, they cannot be easily changed, for example by introducing alternative learning methods in courses (Currie \& Knights, 2003; Hagen et al., 2003).

Social capital (e.g., social contact and networks) is another type of capital that is produced in MBA programs. While social contacts are undoubtedly valuable for the participants of MBA programs, it seems that the elitist features of these networks are rarely brought up in discussion around MBA education (Whitley, Thomas, \& Marceau, 1981). Nevertheless, the exclusive alumni networks created around MBA education should be viewed with a critical eye. In the worst cases, while building connections among alumni, they create potential for inequality and discrimination. The (in)famous "old boy networks" of the leading business schools are probably the best and worst examples of such inclusion or exclusion. However, in Bourdieu's framework, it is also possible to extend this analysis to the social category of those who have acquired an MBA degree in a recognized school or university. In this broader sense, there are invisible yet important networks between those belonging to this specific social category. These networks reproduce existing social structures in corporations and society at large. As Mintzberg (2004) has claimed, such established networks pose risks of corruption for managerial practice, established organizations, and social institutions.

We argue that debate about MBA education has not really come to grips with the importance of symbolic copital. The degree itself serves as a credential, thereby enhancing career prospects or salaries (Collins, 1979; Pfeffer, 2005). But it is also important to note that the symbolic value of MBA 
TÄBLE 1

Specific Forms of Capital in MBA Education

\begin{tabular}{|c|c|c|c|}
\hline $\begin{array}{l}\text { Form of } \\
\text { Capital }\end{array}$ & Content & Official Rhetoric & Problematic Features \\
\hline Intellectual & $\begin{array}{l}\text { Knowledge and skills } \\
\text { (theories, models, practices) }\end{array}$ & $\begin{array}{l}\text { This is the primary product of an MBA } \\
\text { education that helps one to better } \\
\text { understand and manage } \\
\text { contemporary organizations. }\end{array}$ & $\begin{array}{l}\text { The knowledge and skills learned often prove } \\
\text { to be inadequate for the challenges } \\
\text { encountered in contemporary organizations } \\
\text { and even tend to create problems (due to } \\
\text { the specific characteristics of this education } \\
\text { system including scientificity, } \\
\text { instrumentalism, ethnocentrism, and } \\
\text { neocolonialism). }\end{array}$ \\
\hline Social & Social contacts and networks & $\begin{array}{l}\text { This is the secondary value of an } \\
\text { MBA education. }\end{array}$ & $\begin{array}{l}\text { The contacts created often serve more as } \\
\text { elitist (e.g., "old boy") networks than simply } \\
\text { as useful contacts; MBA education also } \\
\text { creates a special social category with } \\
\text { broader implications; this often involves } \\
\text { exclusion and domination/subjugation. }\end{array}$ \\
\hline
\end{tabular}

degrees varies in accordance with the established reputational hierarchy of universities or business schools (for an analogous analysis of French universities, see Bourdieu, 1990). A degree from a prestigious institution is worth more than one acquired from a less prestigious school. The value also depends on the context; in some corporations MBAs are highly valued, while in others they are not. However, in Bourdieu's terms there is much more to the symbolic capital than the degree itself. In particular, a Bourdieusian perspective helps us to see how it is indeed the symbolic aspects that provide means of distinction for graduates of an MBA program. In particular, the educational process leads to the embodiment of a specific kind of habitus that distinguishes MBAs from others-which is the topic that we will concentrate on in the next section.

In sum, viewing MBA programs as a system of exchange involving intellectual, social, and symbolic capital helps to explain why the outcomes of MBA education may appear disappointing from a conventional learning perspective that focuses only on intellectual capital (knowledge). Furthermore, a Bourdieusion analysis helps to explain how each type of capital provides value for the MBAs, and also how the forms of capital are linked with the very problems singled out by critics of MBA programs.

\section{The Process: Inculcating Values and Practices in and Through Habitus}

To better understand the process of learning and socialization, it is useful to focus on habitus. In Bourdieu's theoretical fromework, habitus describes durable dispositions of sensing, perceiving, thinking, and acting that are inculcated through learning and socialization (see also Brubaker, 1993; Bernstein, 1996; Mutch, 2003). In particular, the pedagogical work in MBA programs leads to the inculcation of a particular kind of MBA habitus.

This habitus is in many ways appealing, especially as it appears to combine financial skills and the ability to solve business problems with a specific sense of managerial heroism. This image is also reproduced by the active marketing campaigns of business schools (Sturdy \& Gabriel, 2000). However, this habitus also involves problematic features. Mintzberg (2004), for example, criticizes the emphasis put on financial calculations, short-term gains, and overall belief in managerial control that tend to characterize MBA graduates.

It would, however, be a mistake to think that this habitus is created only during MBA education. On the contrary, as is often the case in higher education in elite schools (Bourdieu, 1970), the students enrolled in MBA programs have already acquired many of the characteristics of the required habitus. 
Following Bourdieu (1970), one would expect that the screening, evaluation, and selection practices of the MBAs would be biased in this sense. Thus, in Bourdieu's model, this education is more about "confirmation" or "cultural assimilation" (Bourdieu, 1970) than the creation of completely new dispositions.

The cultural assimilation process is most often a voluntary one: MBA students are frequently very willing to go through such a reorientation because they hold an ideal MBA habitus in mind. This is shown in studies analyzing the difficulties of introducing more critical learning methods (Currie \& Knights, 2003; Hagen et al., 2003). In such attempts, the well-intended efforts of teachers can clash with the expectations and aspirations of MBA students (Hagen et al., 2003; Fenwick, 2005). Thus, the stereotypical image that students hold about appropriate content and learning methods in MBA programs may constitute a crucial obstacle to change.

This habitus includes many kinds of dispositions, including dress codes and social habits that tend to characterize those who have acquired an MBA education. However, in this context, we want to emphasize the linguistic skills and discursive practices inculcated (Bourdieu, 1982/1991). In our view, it is the ability to speak in a fashionable and convincing manner that reveals the "up-to-date," "competent," and "knowledgeable" image of managers coming out of MBA programs more than anything else. For MBA students, specific discourses provide cognitive models and vocabularies for various kinds of managerial challenges. The extent to which these theories and models are followed in actual management practice is another matter. Mintzberg's (2004) critique indicates that many of the models and ideas learned fit poorly with current needs, are overly theoretical, and at times seem to remain "empty rhetoric."

Nevertheless, this habitus serves as a means of distinction, that is, a reflection of the symbolic capital that some possess and others do not (Bourdieu, 1991, 1996). In the MBA context, this distinction works primarily vis-à-vis those who have not learned to use the most fashionable management models and practices, specific social skills, or to speak in particular ways. In simple terms, the opportunity to master the most fashionable management rhetoric and to be able to use it in a persuasive and convincing manner may be the core value of an MBA education. Indeed, this is probably the most apparent feature of the MBA habitus in everyday social interaction. The value of such language skills should not be underestimated; being able to use the most up-to-date or fashionable concepts probably provides valuable capital in various kinds of organizational settings. By internalizing and then spreading particular discourses, MBA students and graduates sustain and perpetuate the doxa (see also, e.g., Gee, Hull, \& Lankshear, 1996), which is a topic that we shall focus on in the following section. This often implies the technologization of discourse, that is, the use of words and concepts that only "experts of the field" are able to understand. This is a very effective method of both distinction and exclusion.

There is, however, more to the discursive practices inculcated in MBA programs. Discourses not only enable but also constrain specific MBAs. The discursive dispositions learned provide a particular "management grammar"-as Bourdieu would put it-that may prevent a manager from seeking alternative ways of thinking and acting in specific settings. In particular, these discourses may impede the manager's ability to develop better selfawareness and a critical spirit.

From a critical perspective, $\alpha$ crucial issue is the extent to which ethically problematic values and practices are internalized during the education process and become part of the MBA habitus. Flyvberg's (2001) discussion on "phronesis"-which is inspired by Bourdieu's notion of habitus-is illuminating in this respect. Based on the Aristotelian concepts of "episteme" (explicit knowledge), "techne" (technological knowledge), and "phronesis" (practical value-based knowledge), he emphasizes the importance of phronesis as a counterweight to instrumental rationality. Phronesis deals with ethical aspects of knowledge, not only as universal principles, but as part of praxis. The point is to "encourage individuals, organizations and society to think and act in value-rationality terms" (Flyvberg, 2001: 130). In view of concerns about the lack of ethical reflection in MBA education (Grey \& French, 1996; Khurana, 2007; Mintzberg, 2004), it seems appropriate to argue for an increasing focus on phronesis in MBA education in addition to episteme and techne.

It is important to note that Bourdieu's notion of habitus also allows one to reflect on positive development. While learning and socialization in MBA programs can lead to the reinforcement of ethically problematic values and practices in the habitus of MBA graduates, ethically sustainable and practically useful discourses, methods, and practices may also be internalized during this process. Thus, we emphasize the possibility of change that is also part of Bourdieu's theory of habitus (Harker, 1984). Moreover, in line with McNay (1999), we suggest that this education may lead to highly rewarding personal development experiences that encourage reflection and challenge prevailing val- 
ues and practices. However, as mentioned above, larger scale change is not easy and will often confront resistance when it goes against the doxa (the widely shared beliefs of the field), which is what we will focus on next.

In sum, by using Bourdieu's concept of habitus, we can better comprehend how values and practices are inculcated through MBA education. This process is confirmatory in nature and emphasizes distinction vis-à-vis others. Unfortunately, MBA education tends to reproduce widely shared and often ethically problematic values and practices at least as long as phronesis (value-rationality) lacks a stronger position in MBA programs. Nevertheless, change is also possible in this framework, but is difficult if new ideas, models, and methods contradict the doxa.

\section{System: Reproduction of Doxa by Self-Regulation}

MBA education, like any other field, is characterized by its doxa (fundamental beliefs of the system). As explained above, a key theme in Bourdieu's analysis is that the doxa, which has evolved over time, tends to be reproduced as long as it serves to maintain the power position of the pedagogical authorities and the elite in society (Bourdieu, 1970). This reproduction takes place at a micro-level in and through the inculcation of habitus, but also at a macro-level through mimicry and self-regulation.

In Bourdieusian analysis, the most prestigious schools take the lead in setting examples and standards. They form the "center" of the system-in our case business education in general and MBA programs in particular (Bourdieu, 1970, 1984, 1998). Hence, others have to position themselves vis-à-vis the leading institutions. This is apparent both in various attempts to copy and in genuine efforts to create alternative forms and methods for MBA education. The spread and evolution of MBA education has already created various kinds of subfields or niches based on the duration, content, method, and philosophy of the programs. The fact remains, however, that the central position of the leading schools has remained unchallenged, which partly explains the rigidity of the prevailing values and practices.

In MBA education, accreditation and ronkings are particularly important means of self-regulation, the role of which can be elucidated by a Bourdieusian analysis of the doxa. In this view, accreditation agencies not only serve to spread information or develop the quality of MBA programs, which are the espoused objectives of accreditation, but also act as powerful bodies "guarding the doxa"
(Bourdieu \& Passeron, 1990). As shown in discussion of accreditation agencies, this power can impede change in terms of standardization and homogenization (Julian \& Ofori-Dankwa, 2006), which is precisely what one could assume based on Bourdieu's studies of the French education system (Bourdieu, 1988, 1998). One would also expect this standardizing effect to be particularly strong for those schools that have not established their position as part of the "center" of the field. Reputable schools may, in turn, exercise a great deal of influence on accreditation agencies. Their curricula and changes in them often serve as examples for accreditation agencies. Furthermore, representatives of more reputable schools are more easily given voice in debate about educational reform than those from less well-known institutions.

This is not to say that the impact of the accreditation programs and their increasingly widespread adoption is entirely negative. On the contrary, as illustrated in the ongoing debate, the effects may be in many ways positive for specific areas (Zammuto, 2008) or schools (Moskal et al., 2008). For example, accreditation agencies may be able to launch new positive reforms, promote business schools that develop their programs and practices, and weed out institutions that fail to respond to the expectations. However, the gist of Bourdieusian analysis is that institutional actors such as accreditation agencies tend to reproduce the prevailing doxa-including their problematic features. Hence, changes and reforms usually remain limited unless fundamental underlying values and assumptions of this educational field are challenged by powerful actors in the center of the system.

Rankings are a different case in the sense that the regulative power is in the hands of the media. However, at the same time, they provide a "market place" that evaluates schools and programs-with both facilitative and constraining effects on development of MBA education (Zemsky, 2008; DeNisi, 2008; Glick, 2008). A Bourdieusion perspective on this issue is that although change is possible, such evaluation tends to be conservative and reproduce the prevailing doxa (Bourdieu, 1988, 1998). Furthermore, since this evaluation emphasizes issues such as salaries instead of more direct learning results, rankings reinforce the importance of social and symbolic capital at the expense of intellectual capital, and thereby promote instrumental rationality over value-rationality. As Khurana (2007: 369) puts it: "Consider, for example, how external signs of success or failure, approval or condemnation-signs such as the BusinessWeek rankings and the starting salaries of our students-have 
replaced internal markers that might serve to measure the quality of business schools against the high aims that many faculty members and administrators still have for them."

In summary, by applying Bourdieu's ideas around the doxa and its reproduction, one can better understand how accreditation agencies and rankings may impede change in MBA education. Although they con also promote renewal, the prevailing tendency is usually to standardize and homogenize, and thus, also reproduce the problematic aspects of MBA programs.

\section{SUMMARY AND CONCLUSION}

We have taken a Bourdieusian approach to MBA programs. We have argued that it is useful to examine MBA education as a specific form of higher education that has inherent structural characteristics, the analysis of which helps to explain the frequent problems and disappointments related to MBA programs. In particular, we maintain that an application of Bourdieu's theories elucidates three key issues in debate around MBA education: the outcomes of MBA programs, inculcation of values and practices in the process, and the role of selfregulation in the form of accreditation and rankings as a potential impediment to development of MBA programs. First, by distinguishing intellectual (learning), social (social networks), and symbolic capital (credentials and prestige), we can better understand the outcome of MBA education. We contend that prestigious schools, which provide more symbolic capital than less well-known ones, do not have an incentive to make fundamental changes in their programs when this would pose $a$ threat to their established position. Thus, this analysis helps us to comprehend why and how MBA programs remain as popular as they do despite claims that they fail to produce useful knowledge (Mintzberg, 2004). As a consequence, this analysis contributes to discussion on the outcomes of MBA education (Leavitt, 1989; Mintzberg, 2004; Pfeffer \& Fong, 2002).

Second, with the notion of habitus, one can analyze the process of socialization that leads to inculcation of values and practices. In Bourdieu's fromework, this process is often voluntary and involves the legitimation and naturalization of problematic or ethically questionable values and practices. This analysis therefore contributes to critical discussion on the process of learning and socialization in MBA programs (French \& Grey, 1996; Mintzberg, 2004; Ghoshal, 2005; Khurana, 2007).

Third, by focusing on the doxa and its reproduction at the systemic level, Bourdieu's framework helps us to better comprehend how both accreditation and widespread ranking tend to standardize and homogenize, and thus, impede comprehensive change. A Bourdieusion analysis thus aids to advance this debate (Zemsky, 2008; DeNisi, 2008; Glick, 2008; Julian \& Ofori-Dankwa, 2006; Romero, 2008; Zammuto, 2008). Furthermore, we can also see how the outcome, process, and systemic aspects are linked together.

We provide an example of how Bourdieu's theoretical ideas can be used in analyses of management in general and management education in particular. So far such applications have been relatively scarce (Oakes, Townley, \& Cooper, 1998; Ramirez, 2001; Mutch, 2003; Pinington, 2005; Özbilgin \& Tatli, 2005; Golsorki et al., 2009). Moreover, existing analyses have often picked up specific ideas-such as forms of capital-but have not focused sufficient attention on other concepts that are needed to understand the dynamics of complex social systems such as MBA education. We believe that our analysis has shown the power of holistic explanations where notions of capital, habitus, and doxa complement each other.

Our analysis has so far been pessimistic in tone as we have highlighted problematic aspects of MBA education and various complex impediments to change. This is the usual way to interpret Bourdieu, which illustrates the determinism that Bourdieu has often been accused of (Harker, 1984; McNay, 1999; Reay, 2004). According to his critics, Bourdieu's framework does not in the end allow much room for agency, which limits the usefulness of his work in education and other areas. However, it should be noted that Bourdieu can also be read in another way and his concepts used to underscore the possibility of change (Horker, 1984; Reay, 2004). In particular, to view habitus as a grammar of dispositions also enables incremental change. If and when people invent and get excited about new ideas and methods of learning, these can become internalized, spread, and eventually legitimated and naturalized as part of the MBA habitus. By being innovative, one can also find new ways of distinction at university, school, and program levels that may challenge the traditional wisdom. Accreditation agencies may act as impediments to fundamental change, but they can equally succeed in bringing about positive change at a systemic level. In addition, rankings may also improve the system. Furthermore, Bourdieu emphasizes that fundamental transformation is likely to occur at a time of crisis (Bourdieu, 2000). The current financial crisis-coupled with on increasing awareness of the problems and challenges of MBA educationmay indeed trigger fundamental positive change. 
But Bourdieu warns us not to take such development at face value and cautions us to look beyond the espoused objectives and naivve optimism to understand the complexities of the education system.

Our aim here has been to highlight the structural features of the system to better understand the problems and challenges in MBA education, not to provide a list of remedies. Consequently, we wish to take up a few interesting ideas that follow from Bourdieusion or likeminded reasoning. Following the tradition of critical thinking, our argument, like Bourdieu's, is that awareness of potential problems and challenges is a big step forward. In particular, Bourdieu's unconventional framework allows us to concentrate on some of the blind spots that otherwise receive inadequate attention. To understand that value is created not only through intellectual, but also through social and symbolic capital is crucial for broadening our understanding of what students seek and business schools offer. In particular, recognizing the importance of symbolic capital provides a basis to re-evaluate the motivations and attitudes of students as well as the actions and practices of many business schools. To reflect on the MBA habitus and what it entails gives us an opportunity to think hard about the examples provided and the values promoted in MBA programs. To problematize the role of accreditation agencies not only as agents of positive development, but also as impediments to change should help to increase healthy self-criticism.

Following this line of thought, the idea of phronesis (Flyvberg, 2001) may serve as a useful concept that could help direct efforts to deal with the simultaneous problems of the lack of practical value (Mintzberg, 2004) and ethical concerns (Khurana, 2007). Equally of interest, phronesis can be interpreted as a combination of practically relevant value-based rationality. It is, therefore, an ideal of learning and knowledge that goes beyond the emphasis on instrumental and technical knowledge (Roberts, 1996), which is closely linked with turbo-capitalism (Grey, 2002) and an obsession with quick profits (Khurana, 2007). Equally, Bourdieusian ideals con be coupled with Weick's (2007) emphasis on a search for wisdom while making sense of the unexpected as a basis for management education. The ideal is a reflective manager who uses the best available knowledge and ethical judgment to deal with problematic issues. Hence, the reflective manager should be able to critically evaluate both the managerial problems encountered and the solutions offered for dealing with such issues. This is easy to say, but difficult to accomplish in MBA programs. However, there are examples of alternative ways of designing and conducting MBA education, starting from Mintzberg's IMPM program. In a Bourdieusion spirit, the point is not so much to invent something totally new, but to spread and legitimate the alternatives to bring about change.

So far, we have focused on the standard North American-model MBA programs. It should be noted that there are a variety of other forms of business and management education, the problems and challenges of which differ from the ones described here (Kieser, 2004; Kipping, Üsdiken, \& Puig, 2004; Mazza et al., 2005). For example, in many places in Europe, master's degrees are the backbone of business education, and these programs tend to resemble more traditional university education and to be less marketable products. At the same time, these programs can be even more theoretical than the standard MBA programs. Similarly, European MBA programs are often designed for students who already have significant business experience, which makes them different from the typical Northern American alternatives. For example, the doctor of business administration (DBA) education has emerged as form of education that may provide a fruitful basis for personal development in the form of deeper level theoretical reflection that is or should be relevant for practice. It would thus be important to dig deeper into specific forms and types of programs in the United States, Europe, and elsewhere and examine their distinctive features and differences in a detailed manner.

While we have sketched out the elements of $a$ particular kind of critical perspective on MBA education, this analysis should be followed by both more focused theoretical, and in particulor, empirical studies of specific aspects of MBA education programs. There are several issues that deserve special attention. First, while we believe that the points raised are relevant for most MBA programs in most contexts, it would be important to analyze the differences across various types of MBA programs, and by so doing, map out more specific problems and challenges in future research. Second, it would be interesting to go further with the analysis of the different types of capital and their relationships in specific contexts. In particular, it seems to be the case that the symbolic capital provided by different schools is very different. A critical comparative analysis of reputations, ranking, and actual learning results would be most interesting. Such analysis could also consider the "inflation" of MBA education in terms of its decreasing symbolic value in conditions of an increasing number of MBA programs and degrees. Third, it would be important to analyze more closely the reproduction of specific management models 
and fashions in MBA programs (Abrohamson, 1996; Kipping et al., 2004; Mazza et al., 2005). It would be porticularly fruitful to analyze through the lens of symbolic capital the dynamic in which the value of specific concepts and rhetoric decreases over time when new fashions replace old ones. This dynamic may be one of the driving forces of contemporary education systems, but particularly accentuated in MBA programs. Fourth, it would be interesting to examine the linguistic habitus and capital associated with MBA education in more detail. This should involve not only theoretical reflection but also empirical studies in various contexts.

\section{REFERENCES}

Abrahamson, E. 1996. Management fashion. Academy of Management Review, 21(1): 254-285.

Bennis, W. B., \& O'Toole, J. 2005. How business schools lost their way. Harvard Business Review, 83(5): 96-104.

Bernstein, B. 1996. Pedagogy, symbolic control and identity: Theory, research, critique. London: Taylor and Francis.

Bourdieu, P. 1970. La reproduction. Paris: Les Editions de Minuit.

Bourdieu, P. 1980. Le sens pratique. Paris: Les Editions de Minuit.

Bourdieu, P. 1982. Ce que parler veut dire. Paris: Fayard.

Bourdieu, P. 1984. Homo Academicus. Paris: Les Editions de Minuit.

Bourdieu, P. 1988. Homo Academicus. Stanford: Stanford University Press.

Bourdieu, P. 1989. La noblesse d'etat, grandes écoles et esprit de corps. Paris: Les Editions de Minuit.

Bourdieu, P. 1990. The logic of practice. Cambridge: Polity Press.

Bourdieu, P. 1991. Language and symbolic power. Cambridge, MA: Harvard Business University Press.

Bourdieu, P. 1996. Distinction: $A$ social critique of the judgement of taste. London: Routledge.

Bourdieu, P. 1998. State nobility. Elite schools in the field of power. Cambridge: Polity Press.

Bourdieu, P., \& Passeron, J.-P. 1990. Reproduction in education, society and culture. London: Sage.

Bourdieu, P. 2000. Pascalian meditations. Translated by R. Nice. Stanford, CA: Stanford University Press.

Brubaker, R. 1993. Social theory as habitus. In Calhoun, C. LiPuma, E., \& Postone, M. (Eds.), Bourdieu: Critical perspectives: 212-235. Cambridge: Polity Press.

Calhoun, C., LiPuma, E., \& Postone, M. 1992. Bourdieu: Critical perspectives. Chicago, IL: Polity Press, Cambridge and University of Chicago Press.

Cheit, E. F. 1985. Business schools and their critics. California Management Review, 27(3): 43-62.

Chia, R. 2005. The aim of management education. Organization Studies, 26: 1090-1092.

Collins, R. 1979. The credential society: $A$ historical sociology of education and stratification. New York: Academic Press.

Costea, B. 1999. International MBAs and globalisation: Celebra- tion or end of diversity? Human Resource Development International, 2(4): 309-311.

Crotty, P., \& Soule, A. 1997. Executive education: Yesterday and today, with a look at tomorrow. The Journal of Management Development, 16(1): 4-21.

Cruikshank, J. L. 1987. A delicate experiment: The Harvard Business School, 1908-1945. Boston, MA: Harvard Business School Press.

Currie, G., \& Knights, D. 2003. Reflecting on critical pedagogy in MBA education. Management Learning, 34(1): 27-50.

DeNisi, A. 2008. Rain, snow, and sleet are just different types of precipitation. Academy of Management Perspectives, 22: 15-17.

Donaldson, L. 2005. Following the scientific method: How I become a committed functionalist and positivist. Organization Studies, 26: 1071-1088.

Fenwick, D. 2005. Ethical dilemmas of critical management education: Within classrooms and beyond. Management Learning, 36(1): 31-48.

Flyvbjerg, B. 2001. Making social science matter: Why social inquiry fails and how it can succeed again. Cambridge: Cambridge University Press.

Fowler, B. 1997. Pierre Bourdieu and cultural theory: Critical investigations. London: Sage.

French, R., \& Grey, C. 1996. Rethinking management education. London: Sage.

Gee, J. P., Hull, G., \& Lankshear, C. 1996. The new work order: Behind the language of the new capitalism. NSW, Australia: Allen \& Unwin, St Leonards.

Ghoshal, S. 2005. Bad management theories are destroying good management practices. Academy of Management Learning and Education, 4(1): 75-91.

Glick, B. 2008. Rain man or pied piper? Moving business schools beyond media rankings with mass customization and stakeholder education. Academy of Management Perspectives, 22: 18-23.

Golsorki, D., Leca, B., Lounsbury, M., \& Ramirez, C. 2009. Analysing, accounting for, and unmasking domination: On our role as scholars of practice, practitioners of social science and public intellectuals. Organization, 16(6): 779-797.

Gosling, J., \& Mintzberg, H. 2004. The education of practicing managers. MIT Sloan Management Review, 45(4): 19-22.

Grey, C. 2002. What are business schools for? On silence and voice in management education. Journal of Management Education, 26: 496-512.

Grey, C., \& French, R. 1996. Rethinking management education: An introduction. In R. French, \& C. Grey, (Eds.), Rethinking management education: 1-17. Sage: London.

Hagen, R., Miller, S., \& Johnson, M. 2003. The 'disruptive consequences' of introducing a critical management perspective onto an MBA program: The lecturers' view. Management Learning, 34(2): 241-257.

Harker, R. 1984. On reproduction, habitus and education. British Journal of Sociology of Education, 5: 117-127.

Julian, S. D., \& Ofori-Dankwa, J.C. 2006. Is accreditation good for the strategic decision making of traditional business schools? Academy of Management Learning \& Education, 5(2): 225-233.

Khurana, R. 2007. From higher aims to hired hands: The social 
transformation of American business schools and the unfulfilled promise of management as profession. Princeton, NJ: Princeton University Press.

Kieser, A. 2004. The Americanization of academic management education in Germany. Journal of Management Inquiry, 13(2): 90-97.

Kipping, M., Üsdiken, B., \& Puig, N. 2004. Imitation, tension and hybridization: Multiple "Americanizations" of management education in Mediterranean Europe. Journal of Management Inquiry, 13(2): 98-108.

Knights, D. 2008. Myopic rhetorics: Reflecting epistemologically and ethically on the demand for relevance in organizational and management research. Academy of Management Learning and Education, 7(4): 537-552.

Lane, J. F. 2000. Pierre Bourdieu. A critical introduction. London/ Sterling: VA: Pluto Press.

Latham, G., Latham, S. D., \& Whyte, G. 2004. Fostering integrative thinking: Adapting the executive education model to the MBA program. Journal of Management Education, 28(1): 3-18.

Leavitt, H. J. 1989. Educating our MBAs: On teaching what we haven't taught. California Management Review, 31(3): $38-50$.

Linder, J. C., Smith, H. J., \& Jeff, H. 1992. The complex case of management education. Harvard Business Review, 17(5): $16-32$.

Mazza, C., Sahlin-Anderson, K., \& Strandgaard Pedersen, J. 2005. European constructions of an American model: Developments of four MBA programs. Management Learning, 36(4): 471-491.

McNay, L. 1999. Gender habitus and the field: Pierre Bourdieu and the limits to reflexivity. Theory Culture and Society, 16 (1): 95-117.

Mellahi, K. 2000. The teaching of leadership on UK MBA programs: A critical analysis from an international perspective. The Journal of Management Development, 19(4): 297-309.

Mintzberg, H. 2004. Managers not MBAs: A hard look at the soft practice of managing and management development. San Francisco: Berrett-Koehler.

Moskal, P., Ellis, T., \& Keon, T. 2008. Summary of assessment in higher education and the management of student-learning data. Academy of Management Learning and Education, 7(2): 269-278.

Mutch, A. 2003. Communities of practice and habitus: A critique. Organanization Studies, 24(3): 383-401.

Mutch, A., Delbridge, R., \& Ventresca, M. J. 2006. Situating organizational action. Organization, 13(5): 607-625.

Navarro, P. 2008. The MBA core curricula of top-ranked U.S. business schools: A study in failure? Academy of Management Learning \& Education, 7(1): 108-123.

Oakes, L. S., Townley, B., \& Cooper, D. J. 1998. Business planning as pedagogy: Language and control in a changing institutional field. Administrative Science Quarterly, 43(2): 257-293.

Ozbilgin, M., \& Tatli, A. 2005. Book review essay: Understanding Bourdieu's contribution to organization and management studies. Academy of Management Review, 30(4): 855-869.

Parker, M., \& Jary, D. 1995. The McUniversity: Organisation, management and academic subjectivity. Organization, 2(2): 319-338.
Pfeffer, J. 2005. Mintzberg's unasked question. Organization Studies, 26(7): 1093-1094.

Pfeffer, J., \& Fong, C. T. 2002. The end of the business school. Academy of Management Learning and Education, 1(1): 78-95.

Pfeffer, J., \& Fong, C. T. 2004. The business school "business": Some lessons from the US experience. Journal of Management Studies, 41(8): 1502-1520.

Pinington, A. 2005. Learning in a competitive field: MBA students' improvised case studies of HRM. The International Journal of Human Resource Management, 16(4): 615-631.

Ramirez, C. 2001. Understanding social closure in its cultural context: Accounting practitioners in France (1920-1939). Accounting, Organizations and Society, 26(4-5): 391-418.

Reay, D. 2004. It's all becoming a habitus: Beyond the habitual use of habitus in educational research. British Journal of Sociology of Education, 25: 431-444.

Reynolds, M. 1999. Grasping the nettle: Possibilities and pitfalls of a critical management pedagogy. British Journal of Management, 10(2): 171-184.

Roberts, J. 1996. Management education and the limits of technical rationality. In R. French, \& C. Grey, (Eds.), Rethinking management education. London: Sage.

Robbins, D. 2005. The origins, early development and status of Bourdieu's concept of 'cultural capital'. The British Journal of Sociology, 56(1): 13-30.

Romero, E. 2008. AACSBN accreditation: Addressing faculty concerns. Academy of Management Learning \& Education, 7(2): 245-255.

Simpson, R. 2006. Masculinity and management education: Feminizing the MBA. Academy of Management Learning and Education, 5(2): 182-193.

Starkey, K., Hatchuel, A., \& Tempest, S. 2004. Rethinking the business school. Journal of Management Studies, 41(8): 1521-1531.

Spender, J.-C. 2005. Speaking about management education: Some history of the search for academic legitimacy and the ownership and control of management knowledge. Management Decision, 43(10): 1282-1293.

Sturdy, A., \& Gabriel, Y. 2000. Missionaries, mercenaries or car salesmen? MBA teaching in Malaysia. Journal of Management Studies, 37(7): 979-1002.

Üsdiken, B. 2004. Americanization of European management education in historical and comparative perspective: A symposium. Journal of Management Inquiry, 13(2): 87-90.

Wacquant, L. 2005. Pierre Bourdieu and democratic politics: The mystery of ministry. Cambridge: Polity Press.

Weick, K. 2007. Drop your tools: On reconfiguring management education. Journal of Management Education, 31(1): 5-16.

Wensley, R. 2005. Book review: The importance and relevance of managers not MBAs. Organization Studies, 26(7): 1095-1098.

Whitley, R., Thomas, A., \& Marceau, J. 1981. Masters of business - The making of a new elite? London: Tavistock.

Üsdiken, B. 2004. Americanization of European management education in historical and comparative perspective: A symposium. Journal of Management Inquiry, 13(2): 87-90.

Zammuto, R. F. 2008. Accreditation and the globalization of business. Academy of Management Learning \& Education, 7(2): 256-268.

Zemsky, R. 2008. The rain man cometh-again. Academy of Management Perspectives, 22: 5-14. 
Eero Vaara (eero.vaara@hanken.fi) is a professor of management and organization at Hanken School of Economics and visiting professor at EMLYON Business School. He received his PhD from Helsinki School of Economics. Vaara's research interests focus on organizational strategy and change, discourse and narratives, and philosophical and methodological issues.

Eric Faÿ (fay@em-lyon.com) holds a PhD in management science from Université Jean Moulin Lyon3. He is an associate professor in management at EMLYON Business School. Faÿ's current research deals with management as it is taught and practiced from sociological, phenomenological, and psychoanalytical perspectives. 